\title{
Accelerated vs. real time modeling for shelf life: an example with fortified blended foods
}

- Phan Thuy Xuan Uyen *a

- Chambers, Edgar IV

- Padmanabhan, Natarajan ${ }^{\mathrm{b}}$

- Alavi, Sajid ${ }^{b}$

Sensory Analysis Center, Department of Human Nutrition, Kansas State University, USA

Department of Grain Science and Industry, Kansas State University, USA

* Email: uyenphan@ksu.edu, Tel: +1.785.532.0144

(Manuscript Received on September 22 ${ }^{\text {th }}, 2014$; Manuscript Revised December $5^{\text {th }}$, 2014)

\begin{abstract}
Shelf life can be simply defined as the duration of that the food remains acceptable for consumption. Determining shelf life of a product, thus, has become essential in quality control because consumer's demands for safe and high quality products have increased. Accelerated shelf life testing (ASLT), which subjects the food to environments that are more severe than normal to speed up the deterioration process, has long been used in shelf life studies because it can help make decisions more quickly by minimizing time and it minimizes costs. The criterion used to determine shelf life can be the changes in either physical, chemical, biological or sensory characteristics.
\end{abstract}

This study used sensory descriptive properties as the primary criteria to investigate the validity of using Accelerated Shelf Life Testing (ASLT) to determine shelf life of four extruded fortified blended foods (FBFs) compared to a real time model. The real-time environment was set at $30^{\circ} \mathrm{C}$ and $65 \%$ relative humidity, based on the weather in Tanzania, the expected location of product use. The ASLT environment was at $50^{\circ} \mathrm{C}$ and $70 \%$ relative humidity based on a $Q$ factor of 2, which was equivalent to a one-week ASLT equals onemonth real time. The samples were evaluated for aroma and flavor by a highly trained descriptive panel for 3 time points in each shelf life model. Among the eighteen attributes tested, rancid and painty were the main sensory criteria to determine the shelf life of the products.

The ASLT shelf life predictive model was consistent with the real time shelf life for three of the samples. However, it failed to predict the real time shelf life of the fourth similar sample. This affirms the essential use of real time modeling in shelf life study for a new product, even when an accelerated model has been developed for other similar products in the same category. ASLT testing can still be used, but only for early guidance or after validation.

Keywords: shelf life, sensory descriptive, accelerated, real time 


\section{INTRODUCTION}

The quality of most foods and beverages decreases over time. Thus, there will be a time that the product becomes unacceptable. This length of time from production to unacceptability is referred to as shelf life [1]. There are various definitions of shelf life in food technology literature reflecting different stand points. For instance, Labuza and Schmidl [2] took into account the variation in consumer perception of quality to define shelf life as "the duration of that period between the packing of a product and the end of consumer quality as determined by the percentage of consumers who are displeased by the product"; whereas, the Institute of Food Technologists (IFT) in the United States overlooked the fact that consumers might store the product at home for some time before consuming as they defined shelf life as "the period between the manufacture and the retail purchase of a food product, during which time the product is in a state of satisfactory quality in terms of nutritional value, taste, texture and appearance" [3]. For many foods, the microbiological characteristics are often the determining factors for its shelf life; no sensory data are needed [4]. Yet for many other foods, the changes in sensory characteristics occur largely before any risk to consumers' health is reached, especially foods that do not tend to suffer from microbiological changes such as baked goods, flour and so on [4]. The shelf lives of such foods become limited by changes in their sensory characteristics [5]. Therefore, sensory shelf-life estimation of foods has recently become increasingly important and resulted in a need for development and applications of new methodologies [6]. Giménez, et al. [6] also reported that the numbers of articles included in Scopus database including the words shelf-life and food in their title, abstract or keywords has increased 3 times from 2002 to 2011.

Accurate estimation of shelf life is crucial for both manufacturers and consumers, given that consumers' demands for safe and high quality foods has rapidly increased. Sensory shelf life determination based on consumer hedonic scores has been used often in quality control. This approach requires a cut-off hedonic score. For instance, it could be an arbitrary mean acceptance of 5.0 (neither like nor dislike) on a 9-point hedonic scale (e.g.,[7]). However, according to Corrigan, et al. [8], this method does not always accurately reflect consumer behavior in deciding whether to accept or reject a product for consumption and the hedonic cut-off point is likely to be product dependent as some product types will never score highly even when fresh. Giménez, et al. [6] reviewed current methodological approaches from designs to different sensory testing approaches to modeling and data analysis. Those authors confirmed that sensory descriptive analysis using trained panels is another popular approach for sensory shelf life estimation. Muñoz et al. (1992) demonstrated an example of a descriptive evaluation of potato chips and the range of sensory specifications. Lareo, et al. [9] used this methodology for estimating the shelf life of lettuce based on visual appearance. Jacobo-Velázquez and Hernández-Brenes [10] applied it to shelf life of avocado paste. Sensory shelf life also can be determined based on one key attribute. The intensity of rancid flavor was used in Nattress, et al. [11] to estimate the sensory shelf life of dark chocolate containing hazelnut paste while oxidized flavor was the key attribute to determine shelf life of whole milk in Nielsen, et al. [12]. Another challenge with shelf life testing is to develop experimental designs that minimize cost and reduce time while still be reliable and valid [1]. Many food products are expected to have shelf lives of several months or perhaps years, making real time shelf life testing not practical for food companies where decisions need to be made in a timely fashion. Therefore, accelerated shelf life testing (ASLT) often is preferred in industry as it 
satisfies the requirement of time and thus, reduces cost. In ASLT, the food products are subjected to controlled environments in which one or more of the extrinsic factors such as temperature, humidity, gas atmosphere or light are set at a higher-than-normal level. In such environments, the food is expected to deteriorate more quickly, reaching the stage of failure in a shorter-than-normal time. The results obtained from ASLT are then extrapolated to obtain the shelf life estimates at the normal storage conditions [8]. However, according to Robertson [1], ASLT is not very well accepted in the food industry, partly because of a lack of basic data on the effect of extrinsic factors on the deteriorative rate. Products deteriorate in different ways including through chemical, physical and temperature-related changes. Therefore, it's very crucial to understand the mechanisms driving changes during storage to determine the correct accelerating factors to use Corrigan, et al. [8]. Besides, the accelerated storage conditions may cause product quality changes that would not normally occur under normal conditions [13]. Often, to set up an ASLT, a company has to determine an accelerating factor either from experience or a rule-of-thumb or from data of previous similar products. Thus, the deteriorating factor has an uncertainty degree cannot be accounted for in the shelf life estimation [5]. This method also assumes that the new product design has the same acceleration factor [14]. Consequently, ASLT has the possibility of resulting in an inaccurate shelf life.

This study aimed to investigate the validity of using ASLT to estimate the sensory shelf life of extruded fortified blended foods (FBFs) in comparison to using real time shelf life testing. Sensory attributes were used as the key factors to determine the shelf life of the products in both shelf life models.

\section{MATERIALS AND METHODS}

\subsection{Samples}

Fortified extruded foods (FBFs) have been widely used in many different feeding programs by international food-aid organizations such as USAID, WFP, and USDA-FAS. These types of foods are commonly developed by blending corn and soy flour or corn and wheat flour, and then fortified with various vitamins and minerals. FBFs have found a variety of practical use of recipe such as porridge, FBF drink, roasted blended food drink, soup and so on [15]. In an effort to improve the formulation of existing FBFs, FAQR (Recommendation \#18) [16] encourage blend combinations of sorghum-soy, sorghum-pea, millet-soy and rice-soy besides traditional cereals such as wheat and corn. Sorghum grain is home-grown in Africa and has steadily gained importance as the chief nutritional component of foods used in aid programs. Sorghum is seen as an important source of calories and proteins [17] and an enriched source of B vitamin [18] and minerals such as potassium and phosphorus. Therefore, various FBFs have been developed from sorghum flour at the Department of Grain Science of Kansas State University and subjected to shelf life testing. Due to the product's quality as shelf stable, ASLT was mainly employed to determine its shelf life. However, real time testing was also conducted for four samples to validate the results from ASLT.

These four extruded fortified blended foods used as porridges were whole sorghum soy blend (WSSB), whole sorghum soy blend with oil (WSSB+oil), decorticated sorghum soy blend (DSSB) and decorticated sorghum soy blend with oil (DSSB+oil). The samples consisted of a base formulation made of either whole (for WSSB and WSSB+oil) or decorticated (for DSSB and DSSB+oil) sorghum flour $(67.27 \%)$, defatted soy flour $(21.13 \%)$, and whey protein concentrate $(30 \%)$. Then vegetable oil 
(5.5\%) was added to the premixed formulation before extrusion to create the two samples with oil. The premix was then extruded at high energy of $450 \mathrm{rpm}$ with $20 \%$ process moisture. Extruded products were dried at $104^{\circ} \mathrm{C}$ and then cooled at room temperature on a cooling belt. The extruded products were then milled and sieved through a $900 \mu \mathrm{m}$ sieve before micronutrient fortification. WSSB and DSSB were fortified with $3 \%$ mineral, $0.1 \%$ vitamin, and $5.5 \%$ oil while WSSB+oil and DSSB+oil were fortified with only mineral $(3 \%)$ and vitamin $(0.1 \%)$.

\subsection{Shelf life testing design}

The real time storage condition was set at $30^{\circ} \mathrm{C}$ and $65 \%$ relative humidity. These set points were based on the tropical weather of Tanzania, the expected location of product use. The accelerated storage condition was at $50^{\circ} \mathrm{C}$ and $70 \%$ relative humidity. These parameters were based on the $\mathrm{Q}_{10}$ factor [1]. The $\mathrm{Q}_{10}$ value is a temperature quotient that reflects the change in reaction rate for every $10^{\circ} \mathrm{C}$ rise in temperature. Mathematically: $\mathrm{Q}_{10}=$ $\frac{k_{T+10}}{k_{T}} . \mathrm{Q}_{10}$ is also found as the ratio between the shelf life at temperature $\mathrm{T}\left({ }^{0} \mathrm{C}\right)$ to the shelf life at temperature $\mathrm{T}+10\left({ }^{0} \mathrm{C}\right)$ or: $\mathrm{Q}_{10}=\frac{\theta_{S(T)}}{\theta_{S(T+10)}}$. If the temperature difference is $\Delta\left(\Delta=\mathrm{T}_{2}-\mathrm{T}_{1}\right)$ rather than $10^{\circ} \mathrm{C}$, the following equation is used: $\left(\mathrm{Q}_{10}\right)^{\Delta / 10}=\frac{\theta_{S(T 1)}}{\theta_{S(T 2)}}$ [1]. Therefore, with the assumption that the deteriorative factor $\mathrm{Q}_{10}$ was 2, the temperature difference $\Delta=50-30=20\left({ }^{\circ} \mathrm{C}\right)$, the accelerated time intervals corresponding to the real time intervals were shown in table 1 .

\subsection{Descriptive Analysis}

All four FBFs were subjected to both shelf life testing models. At each testing time point, sensory descriptive analysis was conducted to evaluate the flavors and aromas of all samples using a descriptive panel of the Sensory Analysis Center at Kansas State University. This panel consisted of six highly trained panelists who have experienced more than 1000 hours of sensory testing, including grain products.

The samples used in the descriptive analysis testing were porridges made from the fortified flours. The porridge was prepared to $20 \%$ solid content by adding $50 \mathrm{~g}$ flour (either WSSB, WSSB+oil, DSSB, or DSSB+oil) to $230 \mathrm{ml}$ of boiling water, bringing back to a boil and cooking for 2 minutes while continuously stirring with a wooden spoon. Sample was cooked to a final weight of $250 \mathrm{~g}$ by checking the weight at 2 minute and every $10 \mathrm{sec}$ after, if needed. This procedure allowed maintaining the desired solid-water ratio without any need of adding water back. Sample was then placed in a $400 \mathrm{ml}$ beaker to cool down to the serving temperature of 30$35^{\circ} \mathrm{C}$. Approximately $30 \mathrm{~g}$ of porridge was then served in a $120 \mathrm{ml}$ Styrofoam cup labeled with a three digit code. The porridge samples were individually evaluated for 18 flavor and aroma attributes on a 15 -point scale $(0=$ none to $15=$ extremely high) with 0.5 increments using a randomized complete block design. Each sample was evaluated in duplicate in two sessions. The panelists used deionized water, carrots and unsalted crackers to cleanse their palate between samples.

Table 1. Shelf life time interval (weeks) for the corresponding accelerated and real time models

\begin{tabular}{ccc}
\hline Testing time point & $\begin{array}{c}\text { ASLT (weeks) } \\
50^{\circ} \mathrm{C}, 70 \% \mathrm{RH}\end{array}$ & $\begin{array}{c}\text { Real time (weeks) } \\
30^{\circ} \mathrm{C}, 65 \% \mathrm{RH}\end{array}$ \\
\hline 0 & 0 & 0 \\
1 & 6 & 24 \\
2 & 9 & 36 \\
\hline
\end{tabular}




\section{DATA ANALYSIS}

Intensity scores on the 15-point scale were averaged over 6 panelists and 2 replicates to result in an average panel score for each attribute per each sample in both shelf life models. Only the data of the key attributes were presented in this paper.

\section{RESULTS AND DISCUSSIONS}

During the orientation session of 2 hours, the sensory panel developed 7 aromas and 11 flavor attributes to describe the porridge samples. The aromas included grain, musty, cardboard, toasted, brown, rancid, and painty. The flavor consisted of overall flavor, sorghum, soy, starch, toasted, brown, cardboard, musty, rancid, painty and astringent. Among those attributes, rancid and painty were chosen to be the key attributes to determine the shelf life of the products. The acceptable range of these two attributes was set from 0 to 5 on the 15-point scale. Any sample that scored higher than 5 was considered a failure. Table 2 and table 3 show the average panel scores (with standard deviation) for rancid and painty aroma and flavor of all samples in the real time shelf life model. Based on the predetermined criteria of the acceptable range of these two attributes, WSSB + oil, DSSB + oil and DSSB had shelf life of somewhere before 36 weeks or 9 months. Only WSSB was still acceptable after 9 months of storage.

Table 2. Average panel scores for rancid and painty AROMA for the products in the Real time model: time 0 - no storage; time $1-24$ weeks, time $2-36$ weeks. Standard deviations are shown in parentheses.

\begin{tabular}{|l|c|c|c|c|c|c|}
\hline \multirow{2}{*}{ Sample } & \multicolumn{3}{|c|}{ Rancid Aroma } & \multicolumn{3}{c|}{ Painty Aroma } \\
\cline { 2 - 7 } & Time 0 & Time 1 & Time 2 & Time 0 & Time 1 & Time 2 \\
\hline WSSB + oil & $0.58(1.08)$ & $1.58(2.22)$ & $\mathbf{7 . 9 6}(\mathbf{0 . 3 3})$ & $0.13(0.45)$ & $0.71(1.17)$ & $4.21(0.33)$ \\
\hline WSSB & $0.46(0.83)$ & $0.92(1.48)$ & $2.25(0.78)$ & $0.00(0.00)$ & $0.46(0.68)$ & $0.88(1.17)$ \\
\hline DSSB + oil & $0.50(0.76)$ & $0.92(1.57)$ & $\mathbf{6 . 0 0}(\mathbf{1 . 3 3})$ & $0.00(0.00)$ & $0.25(0.58)$ & $3.42(0.59)$ \\
\hline DSSB & $0.50(0.08)$ & $0.33(0.61)$ & $\mathbf{1 1 . 0 4}(\mathbf{2 . 9 4})$ & $0.00(0.00)$ & $0.00(0.00)$ & $\mathbf{9 . 9 2}(\mathbf{3 . 8 7})$ \\
\hline
\end{tabular}

Table 3. Average panel scores for rancid and painty FLAVOR for the products in the Real time model: time 0 - no storage; time $1-24$ weeks, time $2-36$ weeks. Standard deviations are shown in parentheses.

\begin{tabular}{|l|c|c|c|c|c|l|}
\hline \multirow{2}{*}{ Sample } & \multicolumn{3}{|c|}{ Rancid Flavor } & \multicolumn{3}{c|}{ Painty Flavor } \\
\cline { 2 - 7 } & Time 0 & Time 1 & Time 2 & Time 0 & Time 1 & \multicolumn{1}{c|}{ Time 2 } \\
\hline WSSB + oil & $0.88(0.97)$ & $2.00(2.18)$ & $\mathbf{9 . 0 4}(\mathbf{0 . 7 5})$ & $0.08(0.28)$ & $1.00(1.49)$ & $\mathbf{7 . 6 7}(\mathbf{0 . 6 1})$ \\
\hline WSSB & $0.54(0.81)$ & $1.29(1.65)$ & $4.08(1.36)$ & $0.00(0.00)$ & $0.42(0.76)$ & $1.33(1.21)$ \\
\hline DSSB + oil & $0.75(0.89)$ & $1.17(1.64)$ & $\mathbf{8 . 7 1 ( 1 . 4 0 )}$ & $0.00(0.00)$ & $0.33(0.61)$ & $\mathbf{6 . 8 3}(\mathbf{2 . 4 2})$ \\
\hline DSSB & $0.54(0.54)$ & $0.54(0.89)$ & $\mathbf{1 2 . 0 0}(\mathbf{2 . 4 6})$ & $0.08(0.28)$ & $0.13(0.43)$ & $\begin{array}{l}\mathbf{1 0 . 7 9} \\
(\mathbf{3 . 7 1})\end{array}$ \\
\hline
\end{tabular}

The results from the ASLT model (Tables 4 and 5) supported the conclusion drawn from the real time model for WSSB+oil, DSSB+oil and WSSB, but not for DSSB. The ASLT data showed that DSSB had rancid and painty aroma and flavor in the acceptable range at the testing time of 9 weeks, which was assumingly equivalent to a 36 weeks or 9 months in the real time model. In addition, the intensities of these attributes were far below the acceptable threshold, which implied that DSSB's shelf life could be longer than 9 months. This disagreed with the result from the real time model. 
The ASLT model in this study was set up based on the assumption that all four FBFs flours had the same deteriorate factor, which was $\mathrm{Q}_{10}=2$. Yet the result showed that DSSB seemed to have a different deteriorate factor from the other three. As DSSB was completely rancid at 9 months (36 weeks) in the real time model but not yet at 9 weeks in the ASLT model, the $\mathrm{Q}_{10}$ factor of this sample should be smaller than 2, which would result in a longer storage time in the ASLT environment to approach the deteriorate process in real time. This result made sense given the nature of DSSB, which was made from decorticated sorghum flour and did not have oil added before extrusion. The extrusion process, due to its high energy, was expected to affect the fat content in the flour, causing it to rancid. Therefore, WSSB+oil and DSSB+oil, because of the higher amount of oil before extrusion, would go rancid faster than DSSB. In addition, the real time model in this study was, in fact, a controlled environment in an environmental chamber with temperature kept at $35^{\circ} \mathrm{C}$ and humidity always around $65 \%$. Therefore, this real time model can be seen as an ideal given the fact that real weather is not always this stable. Even with this ideal set up, the accelerated model still failed to predict the shelf life of one sample. Thus, if the real time shelf life testing had been conducted at the real location, under the influence of other factors from the weather during the year, the shelf life obtained from this model could be quite different from what was obtained from the accelerated model.

In this case, if ASLT with a $Q_{10}$ factor of 2 had only been conducted with WSSB+oil, DSSB+oil, or WSSB a "valid" accelerated shelf life model might be a logical conclusion. However, using such an ASLT model for DSSB would have predicted a much longer shelf life than actually was found in real life testing. Therefore, ASLT must be used with caution and it is always necessary to validate the ASLT results with real time shelf life testing.

Table 4. Average panel scores for rancid and painty aroma for the products in ASLT model: time 0 - no storage; time $1-6$ weeks, time $2-9$ weeks. Standard deviations are shown in parentheses.

\begin{tabular}{|l|c|c|c|c|c|c|}
\hline \multirow{2}{*}{ Sample } & \multicolumn{3}{|c|}{ Rancid Aroma } & \multicolumn{3}{c|}{ Painty Aroma } \\
\cline { 2 - 7 } & Time 0 & Time 1 & Time 2 & Time 0 & Time 1 & Time 2 \\
\hline WSSB + oil & $0.58(1.08)$ & $0.79(1.07)$ & $\mathbf{9 . 2 9}(\mathbf{0 . 5 4})$ & $0.13(0.45)$ & $0.00(0.00)$ & $\mathbf{5 . 2 9}(\mathbf{1 . 0 1})$ \\
\hline WSSB & $0.46(0.83)$ & $1.79(1.38)$ & $0.67(1.61)$ & $0.00(0.00)$ & $0.13(0.43)$ & $0.42(0.99)$ \\
\hline DSSB + oil & $0.50(0.76)$ & $1.50(1.58)$ & $\mathbf{8 . 3 8}(\mathbf{1 . 7 7})$ & $0.00(0.00)$ & $0.29(0.68)$ & $\mathbf{5 . 1 3}(\mathbf{1 . 2 8})$ \\
\hline DSSB & $0.50(0.08)$ & $0.54(1.01)$ & $0.58(1.50)$ & $0.00(0.00)$ & $0.00(0.00)$ & $0.50(1.33)$ \\
\hline
\end{tabular}

Table 5. Average panel scores for rancid and painty flavor for the products in ASLT model: time 0 - no storage; time $1-6$ weeks, time $2-9$ weeks. Standard deviations are shown in parentheses.

\begin{tabular}{|l|c|c|c|c|c|c|}
\hline \multirow{2}{*}{ Sample } & \multicolumn{3}{|c|}{ Rancid Flavor } & \multicolumn{3}{c|}{ Painty Flavor } \\
\cline { 2 - 7 } & Time 0 & Time 1 & Time 2 & Time 0 & Time 1 & Time 2 \\
\hline WSSB + oil & $0.88(0.97)$ & $2.42(1.25)$ & $\mathbf{9 . 2 5}(\mathbf{1 . 2 5})$ & $0.08(0.28)$ & $0.92(0.97)$ & $\mathbf{5 . 3 8}(\mathbf{0 . 9 1})$ \\
\hline WSSB & $0.54(0.81)$ & $3.42(1.04)$ & $1.88(2.65)$ & $0.00(0.00)$ & $0.79(0.86)$ & $0.50(1.00)$ \\
\hline DSSB + oil & $0.75(0.89)$ & $2.58(1.80)$ & $\mathbf{9 . 5 0}(\mathbf{1 . 0 2})$ & $0.00(0.00)$ & $1.29(1.23)$ & $\mathbf{5 . 7 9}(\mathbf{1 . 1 5})$ \\
\hline DSSB & $0.54(0.54)$ & $2.08(1.25)$ & $1.25(2.29)$ & $0.08(0.28)$ & $0.75(0.98)$ & $0.50(1.06)$ \\
\hline
\end{tabular}




\section{CONCLUSIONS}

This study applied sensory descriptive analysis for estimation of sensory shelf life of several samples of fortified blended foods, which could be used in food aid programs in Tanzania and other countries. The study demonstrated the essential use of real time shelf life testing for a new product, even when an accelerated model has been developed for other similar products in the same category. ASLT testing should be used for early guidance, but the results must be validated using real time testing.

\section{ACKNOWLEDGEMENTS}

The authors specially thank Dr. Akinbode Adedeji and Dr. Lijia Zhu for their assistance and contribution in planning and execution of experiments. The authors also thank Eric Maichel, Trevor Huppert, Ryan Robert, and Susan Kelly for their help to facilitate the extrusion process. Many thanks also go to Valerie Olson, Curtis Maughan, Sirichat Chanadang, and Diane Challacombe at the K-State Sensory Analysis Center for their timely support in conducting sensory testing.

\section{Đánh giá năng lực phương pháp gia tốc và phương pháp thời gian thực tế trong nghiên cứu xác định vòng đời sản phẩm: một ví dụ trên hỗn hợp bột đậu nành và lúa miến có bổ sung vi chất}

- Phan Thụy Xuân Uyên ${ }^{\star a}$

- Chambers, Edgar IVa

- Padmanabhan, Natarajan ${ }^{b}$

- Alavi, Sajid ${ }^{b}$

Sensory Analysis Center, Department of Human Nutrition, Kansas State University, USA

Department of Grain Science and Industry, Kansas State University, USA

\section{TÓM TÁT}

Nghiên cứu này nhằm đánh giá năng lực của phương pháp gia tốc (accelerated shelf life testing-ASLT) trong nghiên cứu xác định vòng đời sản phẩm bằng cách so sánh với phương pháp thời gian thực tế (Real time shelf life
testing-RT). Mẫu nghiên cứu là bốn hỗn hợp bột đậu nành và lúa miến (sorghum) có bổ sung vitamin và khoáng chất, là các sản phẩm sẽ được sử dụng trong các chương trình cứu trợ lương thực của tổ chức cứu trợ Hoa Kì (USAid). 
Mô hình vòng đời sản phẩm theo phương pháp thời gian thực tế có nhiệt độ $30^{\circ} \mathrm{C}$ và độ ẩm tương đối $65 \%$, dựa trên môi trường của Tanzania, là nơi dự trù tiêu thụ sản phẩm. Môi trường bảo quản sản phẩm theo phương pháp gia tốc có nhiệt độ $50^{\circ} \mathrm{C}$ và độ ẩm tương đối $70 \%$, với hệ số gia tốc $Q_{10}$ bằng 2. Dựa vào hệ số gia tốc này, một tuần bảo quản trong môi trường gia tốc sẽ khiến sản phẩm biến đổi tương đương với một tháng bảo quản trong môi trường thực tế. Bốn sản phẩm đều được bảo quản trong cả hai môi trường và được đánh giá phân tích cảm quan ở 3 thời điểm: 0,24 và 36 tuần

\section{REFERENCES}

[1]. G. L. Robertson, Food Packaging and Shelf Life: A Practical Guide: CRC Press, 2009.

[2]. T. Labuza and M. Schmidl, "Use of sensory data in the shelf life testing of foods: principles and graphical methods for evaluation," Cereal foods world (USA), 1988.

[3]. Anonymous, "Shelf Life of Foods," Journal of Food Science, vol. 39, pp. 861-865, 1974.

[4]. T. L. Harry and H. Hildegarde, "Sensory Evaluation of Food: Principles and Practices," ed: Springer, New York, 2010.

[5]. G. Hough, L. Garitta, and G. Gómez, "Sensory shelf-life predictions by survival analysis accelerated storage models," Food Quality and Preference, vol. 17, pp. 468-473, 2006.

[6]. A. Giménez, F. Ares, and G. Ares, "Sensory shelf-life estimation: A review of current methodological approaches," Food research international, vol. 49, pp. 311-325, 2012.

[7]. N. D. Montes Villanueva and M. A. Trindade, "Estimating sensory shelf life of chocolate and carrot cupcakes using acceptance tests," Journal of Sensory Studies, vol. 25, pp. 260279, 2010.

[8]. V. Corrigan, D. Hedderley, and W. Harvey, "Modeling the Shelf Life of Fruit-Filled Snack cho $R T$ và 0,6 và 9 tuần cho $A S L T$. Mùi ôi và mùi sơn là hai đặc tính cảm quan dùng để xác định vòng đời của sản phẩm. Kết quả là mô hình gia tốc chỉ xác định được vòng đời của ba sản phẩm giống với phương pháp thời gian thực tế, còn sản phẩm thứ tư thì cho ra kết quả khác biệt. Vì vậy, phương pháp gia tốc chỉ nên sử dụng để định hướng ở giai đoạn đầu của nghiên cứu vòng đời sản phẩm, còn phương pháp thời gian thực tế vẫn là phương pháp quan trọng và cần thiết để đưa ra chính xác vòng đời của sản phẩm.

Bars Using Survival Analysis and Sensory Profiling Techniques," Journal of Sensory Studies, vol. 27, pp. 403-416, 2012.

[9]. C. Lareo, G. Ares, L. Ferrando, P. Lema, A. GAMbaro, and M. Soubes, "Influence of temperature on shelf life of butterhead lettuce leaves under passive modified atmosphere packaging," Journal of Food Quality, vol. 32, pp. 240-261, 2009.

[10]. D. Jacobo-Velázquez and C. Hernández-Brenes, "Sensory Shelf-Life Limiting Factor of High Hydrostatic Pressure Processed Avocado Paste," Journal of food science, vol. 76, pp. S388-S395, 2011.

[11]. L. Nattress, G. Ziegler, R. Hollender, and D. Peterson, "INFLUENCE OF HAZELNUT PASTE ON THE SENSORY PROPERTIES AND SHELF-LIFE OF DARK CHOCOLATE," Journal of sensory studies, vol. 19, pp. 133-148, 2004.

[12]. B. R. Nielsen, H. Stapelfeldt, and L. H. Skibsted, "Early prediction of the shelf-life of medium-heat whole milk powders using stepwise multiple regression and principal component analysis," International Dairy Journal, vol. 7, pp. 341-348, 1997. 
[13]. D. Kilcast, "What approaches does a leading consultancy firm use to estimate shelf-life when time schedules are short," in Workshop summary: Sensory shelf-life testing. Food Quality and Preference, 2006, pp. 640-645.

[14]. W. B. Nelson, Accelerated testing: statistical models, test plans, and data analysis vol. 344: John Wiley \& Sons, 2009.

[15]. WFP. (2009, 09/21/2014.). World Food Programme Recipes Available at http://www.namamillers.org/issues/foodaid/food-aid-recipes/world-food-programmerecipes/.

[16]. P. Webb, B. Rogers, I. Rosenberg, N. Schlossman, C. Wanke, J. Bagriansky, K.
Sadler, Q. Johnson, J. Tilahun, A. Reese Masterson, A. Narayan, "Delivering Improved Nutrition: Recommendations for Changes to U.S. Food Aid Products and Programs," MA: Tufts University, Boston2011.

[17]. L. Ezeogu, K. Duodu, and J. Taylor, "Effects of endosperm texture and cooking conditions on the in vitro starch digestibility of sorghum and maize flours," Journal of Cereal Science, vol. 42, pp. 33-44, 2005.

[18]. M. Hegedüs, B. Pedersen, and B. Eggum, "The influence of milling on the nutritive value of flour from cereal grains. 7. Vitamins and tryptophan," Plant Foods for Human Nutrition, vol. 35, pp. 175-180, 1985. 